Génét. Sél. Evol., 1987, 19 (3), 279-288

\title{
Rabbit mitochondrial DNA : preliminary comparison between some domestic and wild animals
}

\author{
Hajer ENNAFAA ${ }^{(1)}$, Monique MONNEROT ${ }^{(2)}$, Amel EL GAAÏED (1) \\ and J.C. MOUNOLOU (2) \\ (1) Laboratoire de Génétique, Faculté des Sciences, Campus universitaire, 1060 Tunis, Tunisie \\ (2) Laboratoire de Biologie générale, bâtiment 400, Université Paris-Sud, F 91405 Orsay Cedex
}

\begin{abstract}
Summary
The map of the restriction endonuclease cleavage sites of rabbit mitochondrial DNA (mtDNA) has been established : 41 sites were mapped using 13 enzymes. This genome, although rather large for a mammalian mtDNA (17 $300 \mathrm{bp})$, is organized in the typical vertebrate fashion. For each of 6 wild and 5 domestic rabbits belonging respectively to the subspecies Oryctolagus cuniculus algirus and Oryctolagus cuniculus cuniculus, mtDNA molecules are heterogeneous in size. The length variations of about $100 \mathrm{bp}$ have been assigned to the main non coding region of the genome. Very curiously, according to these preliminary results the mtDNAs of the two subspecies exhibit similar restriction patterns. However, 2 variants were found among the animals examined, one in each population.
\end{abstract}

Key words : Rabbit, mitochondrial DNA, restriction endonuclease.

\author{
Résumé \\ ADN mitochondrial du lapin: \\ comparaison préliminaire entre animaux domestiques et sauvages
}

La carte de restriction de l'ADN mitochondrial (ADNmt) du lapin a été réalisée : 41 sites générés par 13 enzymes de restriction ont été cartographiés. Bien qu'étant assez long pour un ADN mitochondrial de mammifère $(17300 \mathrm{pb})$, ce génome semble être organisé de la même manière que celui des autres vertébrés. Pour chacun des lapins étudiés (6 sauvages et 5 domestiques appartenant respectivement aux sous-espèces Oryctolagus cuniculus algirus et Oryctolagus cuniculus cuniculus), les molécules d'ADNmt isolées n'ont pas toutes la même longueur. Un allongement variable (de l'ordre de $100 \mathrm{bp}$ au plus) de la région non codante du génome est responsable de ces variations de longueur. Curieusement, d'après ces résultats préliminaires, les ADNmt des 2 sousespèces présentent les mêmes profils de restriction. Toutefois, parmi les animaux examinés, un variant a été trouvé dans chaque population.

Mots clés: Lapin, ADN mitochondrial, endonucléase de restriction. 


\section{Introduction}

Living wild and domestic rabbits belong to a unique species Oryctolagus cuniculus which is the sole representative of the Oryctolagus genus. This peculiar situation may be the consequence of several drastic reductions in the number of individuals in the populations since this genus appeared in Middle Pliocene (LoPEZ-MarTineZ, 1977). Today 2 subspecies are differentiated by their morphology, reproductive biology and habitat (LoPEZ-MARTINEZ, 1977) : Oryctolagus cuniculus cuniculus lives in North Western Europe, Oryctolagus cuniculus algirus in Spain, North Africa and the Mediterranean Islands. In this paper we have tried to investigate both the genetic diversity between the 2 subspecies and their intra-population polymorphism using mitochondrial DNA (mtDNA) as a probe. MtDNA is indeed a useful tool : it is a well characterized genome, maternally inherited, which evolves more rapidly than its nuclear counterpart in mammals (BROWN, 1983). We have compared the endonuclease restriction patterns of the mtDNA from wild rabbits (Oryctolagus cuniculus algirus, from Zembra Island, Tunisia) and from domestic ones (Oryctolagus cuniculus cuniculus, a French stock : Fauve de Bourgogne). The cleavage sites have been mapped for one domestic rabbit.

Basically the 2 populations share the same type of mtDNA, as judged on restriction patterns, with one variant in each one. Moreover, some intra-individual length heterogeneity of mtDNA has been observed in all animals. The underlying variations concern a DNA sequence probably homologous to the non-coding region of mtDNA usually bearing the $\mathrm{O}_{\mathrm{H}}$ replication origin (BROWN, 1983).

\section{Material and methods}

\section{A. Animals}

Six wild rabbits belonging to the Oryctolagus cuniculus algirus subspecies were captured on Zembra Island, Tunisia and named $\mathrm{Z} 1$ to $\mathrm{Z} 6$. The 5 domestic ones belonging to the Oryctolagus cuniculus cuniculus subspecies were from the Fauve de Bourgogne stock and named D1 to D5.

\section{B. Isolation of mitochondria}

Animals were analysed individually. Mitochondria were routinely isolated from the liver and, occasionally and independently, from kidney and spleen. After slicing, each organ was homogenized in $20 \mathrm{ml}$ of buffer A $(0.02 \mathrm{M}$ Tris maleate, $0.25 \mathrm{M}$ sucrose ; $\left.0.001 \mathrm{M} \mathrm{MgCl}_{2}, \mathrm{pH}=7\right)$. The homogenate was centrifuged for $10 \mathrm{~min}$ at $700 \mathrm{~g}$ on a $0.4 \mathrm{M}$ sucrose, $0.018 \mathrm{M} \mathrm{CaCl}_{2}, 0.1 \mathrm{M} \mathrm{KCl}$ cushion. The volume of the upper layer was inbrought to $30 \mathrm{ml}$ with buffer $\mathrm{A}$ and recentrifuged $10 \mathrm{~min}$ at $9000 \mathrm{~g}$. The pellet was resuspended in a few $\mathrm{ml}$ of buffer $\mathrm{A}$, layered onto a discontinuous sucrose gradient (20 p. 100,30 p. $100,42.5$ p. 100 ) and centrifuged $70 \mathrm{~min}$ at $25400 \mathrm{~g}$. The mitochondrial band, located at the 42.5 p. $100-30$ p. 100 interface, was recovered, diluted 2 times with buffer $\mathrm{A}$ and centrifuged $15 \mathrm{~min}$ at $9000 \mathrm{~g}$. The pellet was kept at $-20^{\circ} \mathrm{C}$ overnight. 


\section{C. $m t D N A$ preparation}

After thawing, the mitochondrial pellet was lysed in presence of SDS (1 p. 100). Solid $\mathrm{CsCl}$ was then added $(1.2 \mathrm{~g}$ per $\mathrm{ml}$ of lysate). The refractive index of the lysate should be of $1.399-1.400$. The lysate was centrifuged for $20 \mathrm{~min}$ at $25000 \mathrm{~g}$ to eliminate proteins and then for $60 \mathrm{~h}$ at $150000 \mathrm{~g}$. Fractions containing mtDNA were finally dialysed against $0.005 \mathrm{M} \mathrm{NaCl}, 0.005 \mathrm{M}$ Tris $\mathrm{pH}=7.5$.

\section{Restriction endonuclease digestion and electrophoresis of DNA}

MtDNA was digested completely at $37^{\circ} \mathrm{C}$ for 2 or $3 \mathrm{~h}$ with an appropriate amount of restriction endonuclease(s) according to the supplier's specifications.

The DNA fragments were separated by electrophoresis on vertical slab gels of 1 p. 100 agarose or 5 p. 100 Bis-acrylamide in $0.04 \mathrm{M}$ Tris base, $0.02 \mathrm{M} \mathrm{NaAc}, 0.002 \mathrm{M}$ EDTA, $0.002 \mathrm{M} \mathrm{NaCl} \mathrm{pH}=8.05$, overnight at $30 \mathrm{~V}$. Hind III digested DNA (SANGER et al., 1982) and Hinc II digested OX174 RF DNA (SANGER et al., 1977) were used as molecular weight standards for calibration.

\section{E. Analysis of DNA bands in electrophoresis gels}

Both a fluorescence examination (ethidium bromide staining) followed by autoradiography of hybridization with [ $\left.{ }^{32} \mathrm{P}\right]$ labelled mouse mtDNA inserted in pBR 325 : pST41 (BLANC et al., 1981) or autoradiography subsequent to end-labelling of DNA fragments produced by restriction endonuclease digestion (WRIGHT et al., 1983) have been used for this study. On a few preparations we checked that the 2 techniques gave the same results.

\section{F. Physical mapping and inter-individual comparisons}

A physical map of domestic rabbit mtDNA was established by the double digestion method. Inter-individual variability was studied by comparing single digest profiles side by side on the same gels.

\section{G. Genetic map}

The same digest profiles were transferred to nylon membranes and sequentially hybridized with 2 recombinant plasmids carrying Xenopus laevis mtDNA fragments with known coding capacity : pXImEB and pXImBSB (CHAMPAGNE et al., 1984). Prehybridization, hybridization and washing of membranes involve the same solution : $6 \times$ SSC $(0.9 \mathrm{M} \mathrm{NaCl}, 0.9 \mathrm{M}$ citrate $\mathrm{Na}, \mathrm{pH} 7) / 5 \times$ Denhardt's solution $(0.1 \mathrm{p} .100$ bovine serum albumin, 0.1 p. 100 Ficoll, 0.1 p. 100 Polyvinyl pyrrolidone)/0.1 p. 100 SDS. Prehybrization and hybridization were carried out at $55^{\circ} \mathrm{C}$, respectively for $1 \mathrm{~h}$ and overnight. After hybridization, the membranes were washed 6 times for $1 / 2 \mathrm{~h}$ at $55^{\circ} \mathrm{C}$. 


\section{Results}

\section{A. Polymorphism of $m t D N A$}

Thirteen restriction nucleases mostly recognizing 6 base pair sequences were used to digest mtDNA of 11 rabbits ( 6 from Zembra, 5 domestic ones). Figure 1a gives, for each enzyme, the sizes of the fragments obtained. The cleavage patterns were identical for 9 of the 11 animals. The 2 exceptions observed were, respectively, the D1 domestic and the Z2 wild rabbits. D1 mtDNA has an extra Eco RI site which splits the larger fragment into 2 pieces $(700 \mathrm{bp}$ and $10700 \mathrm{bp})$. The occurrence of this Eco RI site has been confirmed by repetitive single digestions and by mapping. Z2 mtDNA is larger than the mtDNAs from the other animals by some $300 \mathrm{bp}$. This sequence is localized in the variable region of the genome (see fig. 1b).

1.a

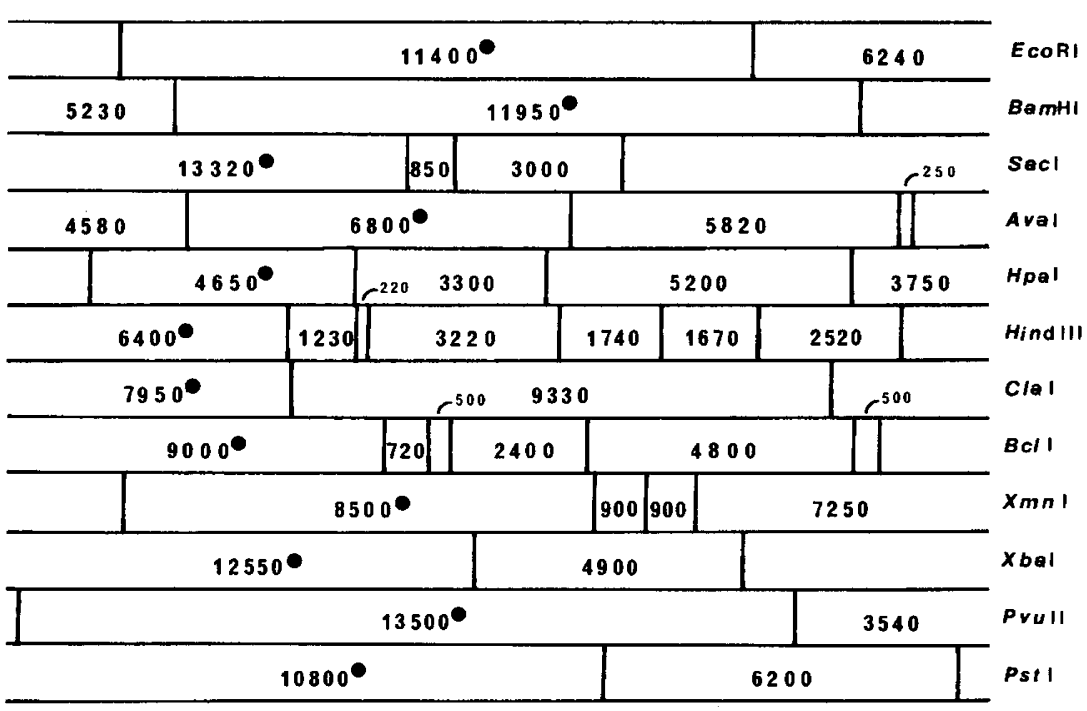

1.b

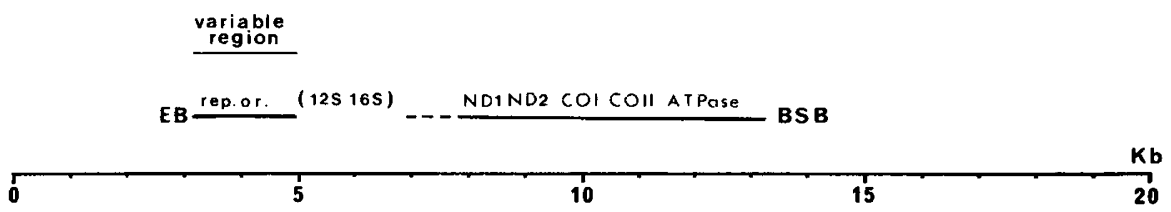

FIG. 1

a) Restriction map of Oryctolagus cuniculus mtDNA. The circular genome has been linearized on the unique Eco $R V$ site. The length variable fragments $(\bullet)$ are indicated for each enzyme.

b) Partial genetic map of Oryctolagus cuniculus $m t D N A$. The extent of the variable region and of the homology with $E B$ and $B S B$ probes is represented by plain lines.

The coding capacity of each probe is given in Results.

The dotted line stands for a region where homology is not entirely assured.

The putative location of $12 S$ and $16 S$ rRNA genes is discussed in the text. 


\section{B. mtDNA cleavage site mapping}

Using the double digestion procedure with the same 13 enzymes a physical map for the «standard» mtDNA has been determined (fig. 1a). Forty restriction sites have been positioned. The precision of the mapping is estimated to be in the range of $\pm 200 \mathrm{bp}$. Our technique does not preclude the occurrence of close restriction sites yielding very small DNA fragments $(<200 \mathrm{bp})$ that would not be detected. The estimated size of the rabbit mitochondrial genome is approximately $17300 \mathrm{bp}$. In order to get more information about the cleavage map, hybridizations of the digestion products were carried out with 2 well defined Xenopus mitochondrial probes (CHAMPAGNE et al., 1984) : BSB (5 $430 \mathrm{bp}$ ) and EB (2 $150 \mathrm{bp})$. BSB is a DNA sequence that bears the following genes : ND1, ND2, COI, COII, subunits 6 and 8 of ATPase, the $O_{L}$ replication origin and several t-RNA genes. The EB sequence includes part of the 12S rRNA and cytochrome $\mathrm{b}$ genes and encompasses the non-coding region, which carries the transcriptional promoters, the CSB sequences (WALBERG \& CLAYTON, 1981) and the $\mathrm{O}_{\mathrm{H}}$ origin of replication (CLAYTON, 1984). Hybridization of rabbit mtDNA with BSB DNA reveals a unique homologous sequence of about $5400 \mathrm{bp}$, limited by $B c l$ I and Hind III sites (see fig. 1b). This suggests that the $B c l$ I-Hind III fragment thus defined carries genes homologous to those of the probe. Similarly, the use of EB DNA is also informative ; it hybridizes with one sequence of about $1800 \mathrm{bp}$, limited by Ava I and Hind III sites (see fig. 1.b). As the ribosomal genes are among the most evolutionarily conserved mitochondrial sequences and the non-coding region the least conserved (CANN et al., 1984) it is tempting to consider that the hybridization signals with EB probe reveal not only the non coding region but also the $5^{\prime} \mathrm{P}$ extremity of the $12 \mathrm{~S}$ rRNA gene.

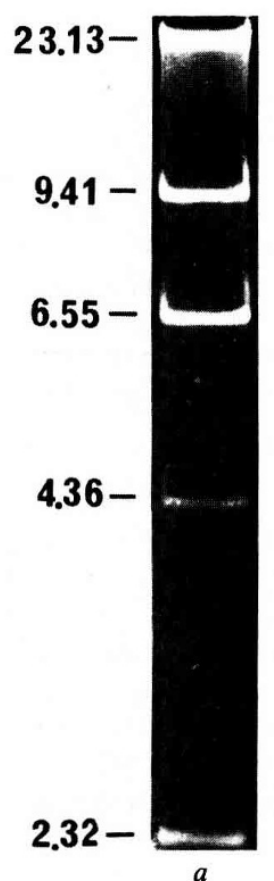

$\boldsymbol{a}$

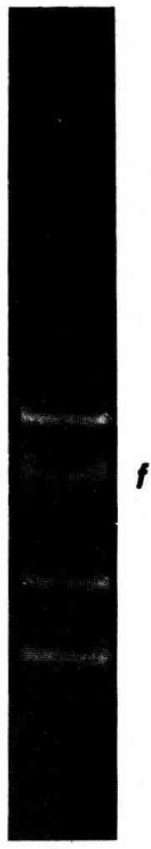

$b$

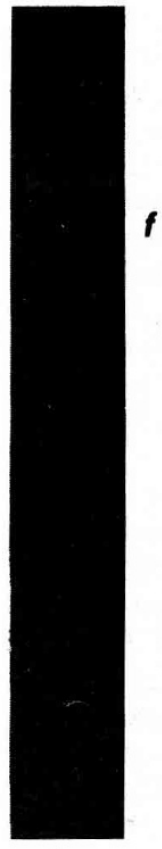

$c$

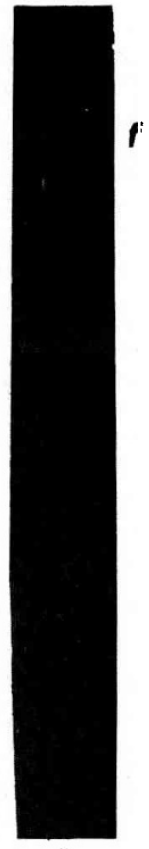

$d$

Fig. 2

Digest patterns of mtDNA from one Oryctolagus cuniculus cuniculus individual with 3 restriction enzymes : $\mathrm{Hpa} \mathrm{I}(\mathrm{b}), \mathrm{Cla} \mathrm{I}$ (c), Pst I (d). Each profile exhibits one fuzzy band : $f$. $a$ : Hind III digest of phage DNA used as a molecular weight standard. 


\section{Intra-individual length heterogeneity}

A careful examination of the gels or of their autoradiographs leads to a peculiar observation (fig. 2) : in addition to the well defined bands, one band appears spread out and fuzzy. Repeats of the digestion with the same enzyme yield the same reproducible pattern. The size of the fragment producing the fuzzy band depends on the enzyme used. A consistent estimate of the overall length of the genome is not obtained if the fuzzy band is not added to the others. This band spreading is thus the indication of an heterogeneous population of homologous DNA fragments with variable lengths. This mtDNA length heterogeneity has been observed in all rabbits whatever their origin (wild or domestic) and whatever the tissue used to isolate the DNA (liver or kidney and spleen). Consequently every rabbit is heteroplasmic and harbors a population of mtDNA molecules of different sizes. The span of the fuzzy band when well resolved yields an estimate of about $100 \mathrm{bp}$ for the range of length heterogeneity. On the cleavage map, all length variable fragments (fig. 1a) are those hybridizing with the EB probe. The length variable region in fig. $1 \mathrm{~b}$ is thus probably within the non-coding region as has been seen in other vertebrate mtDNAs (BRown, 1983).

\section{Discussion}

\section{A. The rabbit mitochondrial DNA}

The only previous piece of information about rabbit mtDNA (BRown, 1981) concerns its size deduced from an electron microscopy examination of 21 molecules : $17300 \pm 400 \mathrm{bp}$. Our estimation of $17300 \mathrm{bp}$ obtained through a different technique agrees well with the already published data, however it could be underestimated for 2 reasons : 1) The precision on the evaluation of mtDNA digestion fragments varies according to their sizes and positions in gels. 2) Our procedure does not allow us to detect and analyse small DNA pieces (less than $200 \mathrm{bp}$ ) that would be generated by very close restriction sites. Despite this, both estimates suggest that rabbit mtDNA is significantly longer than those of man (16 $569 \mathrm{bp}$ : ANDERSON et al., 1981) or mouse (16 295 bp : BiBB et al., 1981) almost as long as that of Xenopus (17 553 bp : RoE et al., 1985).

We have made only two attempts to identify the genetic function of some sequences and to orientate the rabbit mtDNA cleavage map. Hybridizations of rabbit mtDNA with BSB and EB probes (CHAMPAGNe et al., 1984) reveal in each case a unique homologous sequence (see fig. $1 \mathrm{~b}$ ). Both results are consistent with the general principle of conservation of mitochondrial genes (size) and mitochondrial genome organization throughout vertebrates (BROWN, 1983), although a more extensive study with a complete set of smaller probes is clearly necessary. If this is so, the sequence between the putative rabbit $12 \mathrm{~S}$ rRNA gene and the putative NDI-ATPase region which is limited by Hind III and $\mathrm{Bcl}$ I sites (1700-2 $950 \mathrm{bp}$ - fig. 1b) should bridge part of the 12S rRNA and the 16S rRNA genes. This fits with the known length of this gene set in other species ( $2550 \mathrm{bp}$ in mouse for instance) and enables us to orientate the rabbit mitochondrial genome and localize the region encompassing the replication origin on the map according to the position of this region in other vertebrates (fig. 1b). 
Our mapping data clearly show that length variations are restricted to a localized region near the 12S rRNA gene but on the opposite side of the NDI-ATPase region. This is the region of the genome in which we believe the non-coding region is located (fig. 1b). In this region both considerable length and sequence variations are also observed in many species (Fauron \& Wolstenholme, 1976 ; ReIlly \& ThOMas, 1980 ; Brown \& Simpson, 1981; Aquadro \& Greenberg, 1983; Cann \& Wilson, 1983 ; MONNEROT et al., 1984 ; DENSMORE et al., 1985). Length heterogeneity of the mtDNA molecules carried by individuals have been described in some species. In Drosophila (Solignac et al., 1983), heteroplasmic cells have usually 2 types of molecules differing by the number of repeats of a $500 \mathrm{bp}$ unit and they do segregate rather slowly along generations (SolignaC et al., 1984). Likewise in crickets, mtDNA genome exists in 3 size classes and heteroplasmic animals were found bearing 2 size classes of mtDNA molecules (HARRISON et al., 1985). In cows the heteroplasmic animals harbor a family of related mtDNA molecules (continuous variation from 9 to $19 \mathrm{bp}$ in a GC rich region, HAUSWIRTH et al., 1984). Heteroplasmic frogs and lizards probably combine both types of length variation (MONNEROT et al., 1984 and 1986 ; DENSMORE et al., 1985). Our observation of intra-individual length heterogeneity within the mtDNA populations of all rabbits adds one more example to the list of heteroplasmic situations. In rabbit the spectrum of length variations appears continuous and rather more extensive (100 bp) than it is in cows (HAUSWIRTH et al., 1984), but less than in frogs (MONNEROT et al., 1984) or lizards (DENSMORE et al., 1985). Several hypotheses have been put forward to account for length variations: mispairing of homologous sequences and polymerase slippage (BALDACCI \& BERNARDI, 1982), polymerase pause due to secondary structures (KolleK \& Goulian, 1981), unequal crossing-over (Tognon et al., 1983). However the actual events leading to this generalized mitochondrial heteroplasmy are not yet undestood. Regardless of what the mechanisms are, the observation of length heterogeneity of mtDNA in each animal must be the consequence of a high mutational rate and/or a very slow mtDNA purification through segregation at cell division (see discussion in MONNEROT et al., 1984)

\section{B. Inter-individual mtDNA polymorphism}

Inter-individual mtDNA polymorphism is observed among wild animals and domestic ones (Z2 and D1). In both cases the number of rabbits examined are far too small to allow any speculation on the extent of mitochondrial genetic variability. However a future analysis of mtDNA diversity in the Zembra population might be of interest. The actual number of rabbits on the island is of the order of 2000 but is known to have been much more restricted. This population might thus yield a favorable situation to identify maternal lineages and analyse founder effects.

Fauves de Bourgogne on the other hand have been selected in France for a standard type since the beginning of this century from a local stock and crosses have not been conducted in order to isolate maternal lineages (ARNOLD, 1979). The analysis of mtDNA polymorphism could contribute to estimation of the genetic diversity at the origin of this race. It would be interesting to compare this polymorphism to that of the New Zealand Fawn rabbits which have been selected for the same standard out of different breeds. 


\section{Zembra versus domestic rabbits}

Oryctolagus cuniculus algirus is said to have been brought to the Mediterranean Islands from Spain by the Phoenicians some 2 500-3 000 years ago (BoDson, 1978). On the other hand domestication of Oryctolagus cuniculus cuniculus has been a slow process throughout the last few centuries (ARNOLD, 1979). Morphological and physiological criteria easily enable one to differentiate the Fauve de Bourgogne race, which originated from a local stock in Northern France (ARNOLD, 1979) the form wild animals of Tunisia. The characterization of the Ig light chain alleles has shown that the 2 populations are genetically very different (BENAMMAR et al., 1979 ; BENAMMAR \& CAZENAVE, 1981 and 1982). It is thus very surprising to find that both types share the same basic mtDNA, although the number of animals analysed is rather small. This may suggest that both subspecies have evolved from the same stock and that either the "standard " mtDNA has a considerable selective advantage against any mutant form or the number of effective females in both breeds has been drastically reduced in the past (a similar hypothesis was put forward in the case of man, BROWN, 1980). On the contrary, it is known that during the last centuries man has contributed to the disappearance of some mammalian species and the dispersion of others in the Mediterranean Islands (VIGNE \& Alcover, 1985). He may have brought a few domestic females to Zembra Island. In spite of successive back crosses with wild males the mtDNA of these females, maternally inherited, may persist in the population. Such a mitochondrial introgression has occurred in Drosophila mauritiana (SOLIGNAC \& MONNEROT, 1986) and in the mouse (FERris et al., 1983 ; Boursor et al., 1984). A more systematic survey of wild rabbits from various Mediterranean locations and of domestic rabbits from different breeds would certainly help to clarify this point.

Received June 13, 1986.

Accepted November 28, 1986.

\section{Acknowledgements}

This work was supported by funds from NEB and the CNRS-DRST cooperation program. We thank $D^{r}$ BEN SAAD for introducing us to the biology of Zembra Island rabbits and Nicole DENNEBOUY for excellent technical expertise.

\section{References}

Anderson S., Bankier A.T, Barrell B.G., de Bruijn M.H.L., Coulson A.R., Drouin J., Eperon J.C., Nierlich D.P., Roe B.A., Sanger F., Schreier P.H., Smith A.J.H., Staden R., Young I.G., 1981. Sequence and organization of the human mitochondrial genome. Nature, 290, 457-465.

Aquadro C.F., Greenberg B.D., 1983. Human mitochondrial DNA variation and evolution : analysis of nucleotide sequences from seven individuals. Genetics, 103, 287-312.

Arnold J., 1979. Le Fauve de Bourgogne: son historique. L'Eleveur de lapins, 6, 29-31.

Baldacci G., Bernardi G., 1982. Replication origins are associated with transcription initiation sequences in the mitochondrial genome of yeast. Embo J., 1, 987-994. 
Benammar A., Brezin C., Cazenave P.A., 1979. Rabbit immunoglobulin allotypy : a sixth allele at the $b$ locus. Mol. Immunol., 16, 983-987.

Benammar A., Cazenave P.A., 1981. b96 a seventh allele at the rabbit $\mathrm{K}$ chain b locus. Eur. $J$. Immunol., 11, 344-346.

Benammar A., Cazenave P.A., 1982. Rabbit immunoglobulin allotypes : cross-reactivities of the b95 and b96 allotypic specificities with the allotypes of the b series present in domestic rabbits. Ann. Immunol. (Inst. Pasteur), 133c, 365-376.

Bibb M.J., Van Etten R.A., Wright C.T., Walberg M.W., Clayton D.A., 1981. Sequence and gene organization of mouse mitochondrial DNA. Cell, 26, 167-180.

Blanc H., Wright C.T., BibB M.J., Wallace D.C., Clayton D.A., 1981. Mitochondrial DNA of chloramphenicol-resistant mouse cells contains a single nucleotide change in the region encoding the $3^{\prime}$ and of the large ribosomal RNA. Proc. Natl. Acad. Sci. (USA), 78, 3789-3743.

Bodson L., 1978. Données antiques de zoogéographie. L'expansion des Léporidés dans la Méditerranée classique. Les Naturalistes Belges, 59, 66-81.

Boursot P., Bonhomme F., Britron-Davidian J., Catalan J., Yonekawa H., Orsini P., GueraSIMOV S., THALER L., 1984. Introgression différentielle des génomes nucléaires et mitochondriaux chez deux semi-espèces européennes de souris. C. R. Acad. Sci., 299, 365-370.

BRown W.M., 1980. Polymorphism in mitochondrial DNA of humans as revealed by restriction endonuclease analysis. Proc. Natl. Acad. Sci. (USA), 77, 3605-3609.

Brown W.M., 1981. Mechanisms of evolution in animal mitochondrial DNA. Ann. N.Y. Acad. Sci., 361, 119-132.

Brown W.M., 1983. Evolution of animal mitochondrial DNA. In : NeI M., KoEHN R.K. (ed.), Evolution of Genes and Proteins, 62-88, Sinauer, Sunderland, Massachusetts.

Brown G.G., Simpson M.V., 1981. Intra and interspecific variation of the mitochondrial genome on Rattus norvegicus and Rattus rattus. Genetics, 97, 125-143.

CANN R.L., WILSON A.C., 1983. Length mutations in human mitochondrial DNA. Genetics, 104, 699-711.

Cann R.L., Brown W.M., Wilson A.C., 1984. Polymorphic sites and the mechanism of evolution in human mitochondrial DNA. Genetics, 106, 479-499.

Champagne A.M., Dennebouy N., Julien J.F., Le Hegarat J.C., Mounolou J.C., 1984. Colinear organization of Xenopus laevis and mouse mitochondrial genomes. Biochem. Biophys. Res. Comm., 122, 918-924.

Clayton D.A., 1984. Transcription of the mammalian mitochondrial genome. Ann. Rev. Biochem., 53, 573-594.

DENSMORE L.D., WRIGHT J.W., BROWN W.M., 1985. Length variation and heteroplasmy are frequent in mitochondrial DNA from parthenogenetic and bisexual lizards (Genus Cnemidophorus). Genetics, 110, 689-707.

Fauron C.M.R., Wolstenholme D.R., 1976. Structural heterogeneity of mitochondrial DNA molecules within the genus Drosophila. Proc. Natl. Acad. Sci. (USA), 73, 3623-3627.

Ferris S.D., Sage R.D., Prager E.M., Ritte U., Wilson A.C., 1983. Flow of mitochondrial DNA a cross a species boundary. Proc. Natl. Acad. Sci. (USA), 80, 2290-2294.

HARRISON G.R., RAND D.M., WheEleR W.C., 1985. Mitochondrial size variation within individual crickets. Science, 228, 1446-1448.

Hauswirth W.W., Van De Walle M.J., Laipis P.J., Olivo P.D., 1984. Heterogenous mitochondrial DNA D-loop sequences in bovine tissue. Cell, 37, 1001-1007.

Kollek R., Goulian M., 1981. Synthesis of parvovirus H-1 replicative form from viral DNA by DNA polymerases. Proc. Natl. Acad. Sci. (USA), 78, 6206-6210.

LOPEZ-MARTINEZ N., 1977. Revision sistematica biostratigraphica de los lagomorpha (Mammalia) del Neogeno y Cuaternario de Espana. Thesis, Doctorado Ciencias Biologicas, Universidad de Madrid.

Monnerot M., Mounolou J.C., Solignac M., 1984. Intra-individual length heterogeneity of Rana esculenta mitochondrial DNA. Biol. Cell, 52, 213-218.

Monnerot M., Dubois A., Tunner H., 1986. Mitochondrial DNA polymorphism among Rana ridibunda, Rana lessonae and Rana kl. esculenta : preliminary study. Alytes (in press).

ReIlly J.G., Thomas Jr C.A., 1980. Length polymorphism, restriction site variation and maternal inheritance of mitochondrial DNA of Drosophila melanogaster. Plasmid, 3, 109-115. 
Roe B.A., Ma D.P., Wilson R.K., Wrong J.F.H., 1985. Complete nucleotide sequence of the Xenopus laevis mitochondrial genome. J. Biol. Chem., 260, 9759-9774.

Sanger F., Air G., Barell B.G., Brown N.L., Coulson A.R., Fiddes J.C., Hutchison III C.A., SLocombe P.M., Smrth M., 1977. Nucleotide sequence of bacteriophage X174 DNA. Nature, 265, 687-695.

Sanger F., Coulson A.R., Hong G.F., Hill D.F., Petersen G.B., 1982. Nucleotide sequence of bacteriophage DNA. J. Mol. Biol., 162, 729-773.

Solignac M., Monnerot M., Mounolou J.C., 1983. Mitochondrial DNA heteroplasmy in Drosophila mauritiana. Proc. Natl. Acad. Sci. (USA), 80, 6942-6946.

Solignac M., Genermont J., Monnerot M., Mounolou J.C., 1984. Genetics of mitochondria in Drosophila : mtDNA inheritance in heteroplasmic strains of $D$. mauritiana. Mol. Gen. Genetics, 197, 183-188.

SOlignac M., Monnerot M., 1986. Race formation, speciation and introgression within Drosophila simulans, and $D$. sechellia inferred from mtDNA analysis. Evolution (in press).

Tognón M., Cassai E., Rotola A., Roizman B., 1983. The heterogenous regions in herpes simplex virus I DNA. Microbiologica, 6, 191-198.

Vigne J.D., Alcover J.A., 1985. Incidence des relations historiques entre l'homme et l'animal dans la composition actuelle du peuplement amphibien, reptilien et mammalien des îles de Méditerranée Occidentale. Actes du $110^{\circ}$ Congrès National des Sociétés Savantes, Section Sciences, 10-13 avril 1985, Montpellier, 2, 79-91, CTHS, Paris.

Walberg M.W., Clayton D.A., 1981. Sequence and properties of the human KB cell and mouse L cell D-loop regions of mitochondrial DNA. Nucleic Acids Res., 9, 5411-5421.

Wright J.W., Spolsky C., Brown W.M., 1983. The origin of the parthenogenetic lizard Cnemidophorus laredoensis inferred from mitochondrial DNA analysis. Herpetologica, 39 (4), 410-416. 